\title{
OIDDE Learning Model: Improving Higher Order Thinking Skills of Biology Teacher Candidates
}

\section{Husamah}

University of Muhammadiyah Malang, Indonesia, usya_bio@yahoo.com

\section{Diani Fatmawati}

University of Muhammadiyah Malang, Indonesia, dianifatmawati87@gmail.com

\section{Dwi Setyawan}

University of Muhammadiyah Malang, Indonesia,dwis091187@gmail.com

As the massive advancement in 21 st century, the role of education is to prepare generations in mastering the skills they need to face the challenges arised in their era. OIDDE is the abbreviation for Orientation, Identify, Discussion, Decision, and Engage in behaviour. The learning model designed by Hudha et al. (2016) is expected to be able to guide the learners to achieve Higher Order Thinking Skills (HOTS) in term of producing proper and wise decisions through the certain steps which enable them to comprehend the facts faced and engage the decision resulted in their behaviour. This research provides the information of how OIDDE can stimulate the students' higher order thinking skills by assessing the three aspects thinking skills namely: self-regulated thinking, critical thinking, and creative thinking. This research employed Classroom Action Research (CAR) method conducted in two cycles which comprise of four meetings with duration of $3 \times 50$ minutes for each cycle. The participants were 45 biology education students in fifth semester.

Keywords: biology teacher candidates, higher order thinking skill, OIDDE, learning model, thinking skills

\section{INTRODUCTION}

The $21^{\text {st }}$ century learning demands the students to gain more skills in term of developing and digging their knowledge. As the advancement of many aspects such as computational science, mathematics, engineering, and technology in the globalization frame has been giving many advantages in human's life, the education field is now attempting to improve the instructional models which guide the students to not only learn by rote but also to think in profound and complex manner (Gullamhussesin, 2013; Nesbitt-Hawes, 2005). However, the proliferation of discoveries and inventions has

Citation: Husamah, Fatmawati, D., \& Setyawan, D. (2018). OIDDE Learning Model: Improving Higher Order Thinking Skills of Biology Teacher Candidates. International Journal of Instruction, 11(2), 249-264. https://doi.org/10.12973/iji.2018.11217a 
been daunting challenge due to the problems rose by the solutions that work across purposes. While the inventions in technology are massively developed by people, on the other hand, environmental issues follow and even become more common and apparent with industrialization (Dunlap \& Jorgenson, 2012). This changes have, directly or not, been affecting people's life (Hudha et al., 2016). Thus, life competences for biology teacher candidates in this era are crucial to be enacted. In addition, by considering the various conditions, sharp skills as considerable as professionalism are required (Gullamhussesin, 2013). These factors will enable the $21^{\text {st }}$ generation to accommodate changes in both the type and quantity of knowledge. In other words, as society continues to change, the students will be confronted go beyond the simple learning of facts and content (Husamah, 2015; Nesbitt-Hawes, 2005).

Life science, in term of integrated biological sciences with physical, computational sciences, mathematics, and engineering, is one of critical subject to build a more expanded biological enterprises with the scope and expertise to address a broad range of scientific and societal problems (National Research Council, 2009). As the results, the education system, as well as teacher professional education curriculum (Ball \& Forzani, 2009; Handler, 2010; Okeke \& Drake, 2014), has to cultivate the skills which allow the learners to think independently i.e. higher order thinking skill. By having this skill, not only do the teacher candidates comprehend the cases they face, but they also will be able to analyse them and make wise decisions.

Science teacher is one of the most determining factors involved in the educational field. They have an important role in educating the generations to enact the learning goal (Bashir et al., 2014; Mukeredzi, 2013; Setyaningrum \& Husamah, 2011) as they are the 'manager' in the classroom. Teacher is the one who regulates the students' activities in the classroom, they manage as well as facilitate the students to optimize their ability in finishing the tasks given. The effectiveness and efficiency in learning creative management will be achieved as the teachers' competency in managing the instructional processes through learning by doing in real context and direct experiences have been encompassed (Chantarasombat, 2007; Nesbitt-Hawes, 2005; Pukdeewut et al , 2013).

The ability to collaborate with many sectors of educational community has to be mastered by the $21^{\text {st }}$ century teachers (Selvi, 2010; Shaik \& Khoja, 2011). Moreover, technology has been effecting the ways of education, teaching, and learning (Minocha et al., 2010) as well as the teachers' role (Anastasiades \& Vitalaki, 2011; Mukeredzi, 2013; Shaikh \& Khoja, 2012). As the consequences, the teacher candidates are required to master higher order thinking skills. By habituating them to comprehend the sciences, teacher candidates are educated to be ready to guide their future students in tackling the issues come.

Higher order thinking skills including critical thinking (Brookhart, 2010), logical, reflective, metacognitive, and creative thinking (King et al., n.d.). The skill of thinking is indicated by students' ability in implementing wise judgment or produce a reasoned critique. Therefore, six skills are considered to be achieved by students: 1) the ability to judge a source credibility; 2) identify assumptions, generalizations and biases; 3) identify connotation in language use; 4) understand the purpose of a written or spoken 
text; 5) identify the audience; 6) make critical judgments about the relative effectiveness of various strategies used to meet the purpose of the text (Collins, 2014).

However, it is still a big challenge for most teachers to find a proper learning model to construct the higher order thinking skills in students. In Biology Education Department, Faculty of Teacher Training and Education, University of Muhammadiyah Malang, the pre cycle data shows that the students' HOTS were still in 'low' category which were $59 \%, 58 \%$, and $57 \%$ for self-regulated thinking, critical thinking, and creative thinking respectively. Hudha et al. (2016) mentioned that not all of learning model can be implemented by teachers for all subjects, especially to character-integrated sciences. The appropriate creative design of learning activities in learning processes can only be encouraged by the creative teachers who have the good classroom management skills (Pukdeewut et al., 2013). Therefore, it is important to choose the proper instructional techniques to strengthen teacher candidates' higher order thinking skills in terms of SelfRegulated Thinking, Critical Thinking, and Creative Thinking.

OIDDE is an acronym for Orientation, Identify, Discussion, Decision, and Engage in behaviour (Hudha et al., 2016). This Instructional model was developed by Atok Miftachul Hudha, who is senior lecturer of Biology Education Department, Faculty of Teacher Training and Education, University of Muhammadiyah Malang. Based on the modification of two kinds of learning model, behavioural systems (Joyce \& Weil, 1978) and tri prakoro (Akbar, 2013), OIDDE is expected to be an effective "tool" to stimulate learners' HOTS, mainly in dealing with moral and ethical issues. There are five steps in OIDDE which guide the teacher candidates to achieve the $21^{\text {st }}$ century learning demand, in which their role is facilitator rather than instructor.

Some researchers have implemented OIDDE model on various subjects which gained significant result of teacher candidate's abilities in thinking (Setyawan, 2017) and ethical decision making (Pantiwati et al., 2016). However, in order to gain the more holistic data about the effectiveness of OIDDE learning model, it is needed to implement it in the wider various subject conditions. Thus, the aim of this research was describing the way OIDDE stimulates students' higher order thinking skills by measuring the three thinking aspects i.e. self-regulated thinking, critical thinking, and creative thinking. In the other words, this research was purposed to test whether OIDDE instructional model can be utilized to improve the teacher candidates' HOTS.

\section{METHOD}

\section{Type and Approach}

This research employed Classroom Action Research (CAR) which was utilized to observe the teacher candidates' Higher Order Thinking Skills (HOTS). There were three aspects measured namely: Self-Regulated Thinking, Critical Thinking, and Creative Thinking during the learning processes conducted by using OIDDE model. The data were taken three times in pre-cycle, cycle I, and cycle II.

This research was conducted in two cycles with two meetings for each cycle with duration of $3 \times 50$ minutes (three credits) in which all of the teaching and learning 
processes were done based on Lesson Study (LS). It is a supervising model for professional educators through collaborative and continuous learning study based on collegiality and mutual learning in constructing learning community (Syamsuri \& Ibrohim, 2011). LS comprises of plan, do, and see stages. Furthermore, each cycle research contained four stages: planning, action, observation, and reflection. The planning aimed to prepare the treatment, action schedule, and all of the instruments needed (classroom action planning, student worksheet, observation sheet, and questionnaire). Whereas the activities conducted in action stage were the implementation of planning stage, in which the observation process by observers was also done during this stage. The reflection stage was addressed to evaluate the strength and weakness of three previous stages. Thus, the reflection results of cycle I would be the database to consider and improve the next cycles.

\section{Time and Location}

This research was conducted on November 2016 to July 2017 in Biology Education Department, Faculty of Teacher Training and Education, University of Muhammadiyah Malang.

\section{Study Subjects}

The subjects employed were 45 students in fifth semester, academic year 2016/2017 of Biology Education Department, Faculty of Teacher Training and Education (FTTE) University of Muhammadiyah Malang.

\section{Instruments}

The higher order thinking skills were measured by using critical thinking assessment rubric by Marzano (1992). There were three components assessed in this research i.e. self-regulated thinking skill, critical thinking skill, and creative thinking skill. The assessment was conducted three times: pre-cycle, cycle I, and cycle II. In addition, as Lesson Study was employed in this research, there were several instruments used: 1) study journal; 2) Plan, Do, See sheets; 3) observer and lecturer sheets.

\section{Data Analyses}

The data obtained were analysed qualitatively by considering the lecturer's journal and observer sheets as well as the students' scores. The data analysis comprised of arranging the raw data, serve the data, making conclusion, and reflection. The quantitative data obtained were analysed by using percentage formula (Arikunto, 2001) as below.

Score percentage $=\frac{\text { The score gained }}{\text { The maximum score }} \times 100 \%$

Then, the percentage scores were analysed by using Paired Sample t Test and utilizing SPSS software 21 version.

\section{FINDINGS}

Higher order thinking skills (HOTS) contain several skills of thinking namely: critical, logical, reflective, metacognitive, and creative thinking (King et al., n.d.). In other words, they include all intellectual tasks which call for more than information retrieval (Baker, 1989). Meanwhile, Brookhart (2010) has categorized HOTS definitions into the 
terms of transfer, critical thinking, and problem solving. All those definitions refer to the achievements of individual competencies in encountering complex issues, uncertainties, questions or dilemmas.

The existing evidence of higher order thinking in OIDDE learning model implementation is providing reassurance that the skills occur in learning process: 1) the students conform towards various issues related to certain topics through stories, narration, or documenter film (orientation); 2) the students analyse problems based on dilemma found during orientation process (identify); 3) the students altercate the solving of chosen issue by considering the ethically identification results (discussion); 4) as the ethical dilemma has been discussed, the students adjudge (decision); 5) the students behave ethically as the ethical decision taken (engage in behaviour) (Hudha et al., 2016). In turn, the higher order thinking skills are indicated by students' behaviour and statement, explanation, decisions, performances, contextually valid products, the availability of knowledge and experience and promote continuous growth in these and other intellectual skills (Kenimer \& Morgan, 2003). Thus, learning environment (Hoekstra \& Korthagen, 2011) and appropriate teaching strategies are crucial factors to facilitate the thinking skills advance as the learners possess persistence, self-monitoring, and open-minded as well as flexible attitudes (King et al., n.d.).

The students' higher order thinking skill (HOTS) was represented by the three aspects assessed namely: Self-Regulated Thinking, Critical Thinking, and Creative Thinking. In general, the scores witnessed rising trend from preliminary observation to the cycle I and continued to cycle II.

Table 1

The Score Percentage of Students' HOTS

\begin{tabular}{|c|c|c|c|c|c|c|c|c|c|c|c|c|c|c|c|}
\hline \multirow{2}{*}{ Activities } & \multicolumn{5}{|c|}{ Self-Regulated Thinking } & \multicolumn{6}{|c|}{ Critical Thinking } & \multicolumn{4}{|c|}{ Creative Thinking } \\
\hline & A & B & $\mathrm{C}$ & $\mathrm{D}$ & $\mathrm{E}$ & $\mathrm{F}$ & G & $\mathrm{H}$ & I & $\mathrm{J}$ & $\mathrm{K}$ & $\mathrm{L}$ & M & $\mathrm{N}$ & $\mathrm{O}$ \\
\hline Pre-cycle & 59 & 62 & 56 & 60 & 59 & 57 & 60 & 59 & 54 & 57 & 61 & 57 & 54 & 58 & 58 \\
\hline $\begin{array}{l}\text { Mean of Each } \\
\text { Component }\end{array}$ & \multicolumn{5}{|c|}{59 (low) } & \multicolumn{6}{|c|}{58 (low) } & \multicolumn{4}{|c|}{57 (low) } \\
\hline Cycle I & 74 & 72 & 71 & 69 & 73 & 70 & 71 & 71 & 66 & 70 & 72 & 68 & 67 & 69 & 68 \\
\hline Improvement & 14 & 10 & 14 & 9 & 14 & 13 & 11 & 13 & 12 & 13 & 11 & 11 & 13 & 11 & 11 \\
\hline $\begin{array}{l}\text { Mean of Each } \\
\text { Component }\end{array}$ & \multicolumn{5}{|c|}{72 (fair) } & \multicolumn{6}{|c|}{70 (fair) } & \multicolumn{4}{|c|}{68 (fair) } \\
\hline Cycle II & 86 & 81 & 82 & 81 & 78 & 79 & 79 & 84 & 78 & 81 & 84 & 79 & 77 & 81 & 84 \\
\hline Improvement & 12 & 9 & 11 & 12 & 5 & 9 & 9 & 13 & 12 & 11 & 12 & 11 & 10 & 11 & 16 \\
\hline $\begin{array}{l}\text { Mean of Each } \\
\text { Component }\end{array}$ & \multicolumn{5}{|c|}{82 (very good) } & \multicolumn{6}{|c|}{81 (very good) } & \multicolumn{4}{|c|}{80 (very good) } \\
\hline
\end{tabular}

Table 1 shows that the mean values of the three thinking components i.e. self-regulated thinking, critical thinking, and creative thinking scores witnessed upward trend. It started from 59\%, 58\%, and 57\% for self-regulated thinking, critical thinking, and creative thinking respectively which are categorized as low (measured at preliminary observation). It then continued higher and reached the fair level in the cycle I ( $72 \%$, 
$70 \%$, and $68 \%$ ); whereas it climbed to the peak in the cycle II: $82 \%, 81 \%$, and $80 \%$ in sequence. The significant increase was experienced by the thinking components assessed as much as $23 \%$ for each.

The significance of the above percentage rising trends were also supported by the statistical analysis results (Table 2). It is obvious that each component of thinking skills has the significant value less than 0.05 , i.e. 0.000 for the three components (selfregulated thinking, critical thinking, and creative thinking); which means that the students' HOTS have outstandingly increased.

Table 2

The Statistical Analysis Results of Student' HOTS

\begin{tabular}{|c|c|c|c|c|c|c|c|}
\hline \multirow{3}{*}{$\begin{array}{l}\text { Thinking Skill } \\
\text { Components }\end{array}$} & \multirow{3}{*}{ Mean } & \multicolumn{4}{|c|}{ Paired Differences } & \multirow{3}{*}{$\mathrm{T}$} & \multirow{3}{*}{$\begin{array}{l}\text { Sig. (2- } \\
\text { tailed) }\end{array}$} \\
\hline & & \multirow[t]{2}{*}{$\begin{array}{c}\text { Std. } \\
\text { Deviation }\end{array}$} & \multirow[t]{2}{*}{$\begin{array}{l}\text { Std. Error } \\
\text { Mean }\end{array}$} & \multicolumn{2}{|c|}{$\begin{array}{l}\text { 95\% Confidence } \\
\text { Interval of the } \\
\text { Difference }\end{array}$} & & \\
\hline & & & & Lower & Upper & & \\
\hline $\begin{array}{l}\text { Self-Regulated } \\
\text { Thinking }\end{array}$ & -.13185 & .04549 & .00875 & -.14985 & -.11386 & -15.060 & .000 \\
\hline Critical Thinking & -.23000 & .03126 & .00602 & -.24236 & -.21764 & -38.237 & .000 \\
\hline Creative Thinking & -.22593 & .04822 & .00928 & -.24500 & -.20685 & -24.346 & .000 \\
\hline
\end{tabular}

As the upward trend showed, it can also be seen that the three components of HOTS are supporting each other. The higher the level of self-regulated thinking and critical thinking, the more creative the students will be. Regarding these findings. Husamah \& Pantiwati (2014) and Rustaman (2008) stated that as well as someone's self-confidence and personality in facing problems, her/his thinking skills are also built by the three components inseparably, like a concert, in which each component takes its role to organize thinking skills.

To be elaborated more detail, the bar chart of Figure 1 shows us the rising trend of selfregulated thinking sub components which are represented by A (the awareness of selfthinking way), B (the effectiveness in making plans), $\mathrm{C}$ (the awareness in using resources needed), D (the sensitivity of feed backs given), and $\mathrm{E}$ (the evaluation of the effectiveness of every decision taken).

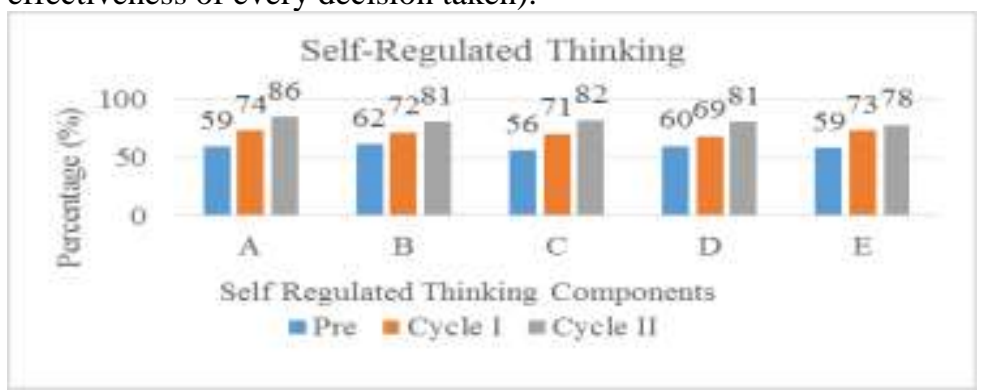

Figure 1

The percentage of students' self-regulated thinking score improvement per cycle 
Notes:

A. The awareness of self-thinking way

B. The effectiveness in making plans

C. The awareness in employing resources needed

D. The sensitivity of feed backs

E. The evaluation self-decision

The greatest rising percentage occurred in sub component $\mathrm{A}$ of $27 \%$, in which the second place was sub component $\mathrm{C}$, while the lowest percentage was sub $\mathrm{B}$ and $\mathrm{E}$ of $19 \%$. This means that not only does the students' awareness was greatly improved as they were taught by using OIDDE model, but also the awareness in using resources needed as well. Notwithstanding that the effectiveness in making plans and its evaluation were lesser developed than those two sub components, but the improvement gained was still categorized as "very good". Pantiwati et al. (2016) stated that the implementation of OIDDE through Integrated Field Study Abroad has improved the biology teacher candidates' ethical decision skills.

Students' Self-regulated thinking skill in pre-cycle was considered as low. According to the observer's note, there were less than five of 45 present students who participated in the classroom discussion by asking questions or giving opinion. Husamah, as one of observer in the classroom noted:

"There just four students asked questions and gave their opinion, yet the questions were shallow; while the others seemed hesitate to express their opinion or ask question, thus, they just discussed with the friends beside them or quite".

This condition was in contrast with the ideal expected. Boekaerts \& Corno (2005) defined that self-regulation is individual consistency in organizing and managing their thoughts, emotions, behaviour and environment through proactive process to enact academic goals.

Moreover, most of the students were tended to confuse to generate the idea, which is a key factor (Yee et al., 2012) in achieving assignments given by the lecturer This confusedness was implied in questions they tried to answer. Lindariyanti's question, as one of frequently asked question type among the students in the classroom, was:

"Sir, is it possible for us to use local wisdom as the solution of the issues we chose?"

Notwithstanding that questioning is a means to encourage the students to think (Larkin, 2002); sporadically accessing the project to encompass the resources needed and looking for various alternatives are, somehow, considered as low level of self-regulated thinking skill (Marzano, 1992).

Teacher quality is one of the education quality determinants (Fadlan, 2010). This because teacher is the role which is tended to be a model (Lunenberg, Korthagen, \& Swennen, 2007) and influencing people, not only for students but also the other surrounding and work field (Brown \& Trevino, 2006). Considering the crucial role, the biology teacher candidates must have good comprehension about self-regulated thinking 
skill and be habituated with it since in their higher education level. This, in turn, will be addressed to build their professionalism level when they get a job. The professionalism involves ethics, social responsibility, critical self-reflection, and self-responsibility (Pantiwati et al., 2016).

As self-regulated thinking skill has been developed in cycle I and cycle II, the critical thinking skill was also getting better as well. This can be seen at Figure 2. It can be seen that the highest improving percentage occurs in H sub component, 'open-minded', as high as $25 \%$, while the lowest was sub component $\mathrm{G}$ of $19 \%$ which is 'clear and willing in attempting the clearness'. The all components were witnessed upward trend and reached 'good' level in cycle II in spite of considered as 'low' level in pre-cycle.

The more the students encounter unfamiliar issues, uncertainties, or dilemmas, the sharper the analysis they have will be (King et al, 1998; Martin, 1989). Through orientation, identification, discussion, decision and engaging in behaviour, the students gained more awareness about their surroundings. Thus, they became more critical in term of making reasons (Grossen, 1991) and reflections which lead them to emphasize about what should be believed and done in making their decisions (Lestari, Nurmilawati, \& Santoso, 2015). In the other words, by managing the analytical and strategic thinking behaviour, the critical thinking can be developed (Oak, 2009) as Marzano (1992) has defined thinking skill as 'Habits of Mind'. This means possessing smart behaviour in tackling difficult problems faced (Costa \& Kallick, 2000).

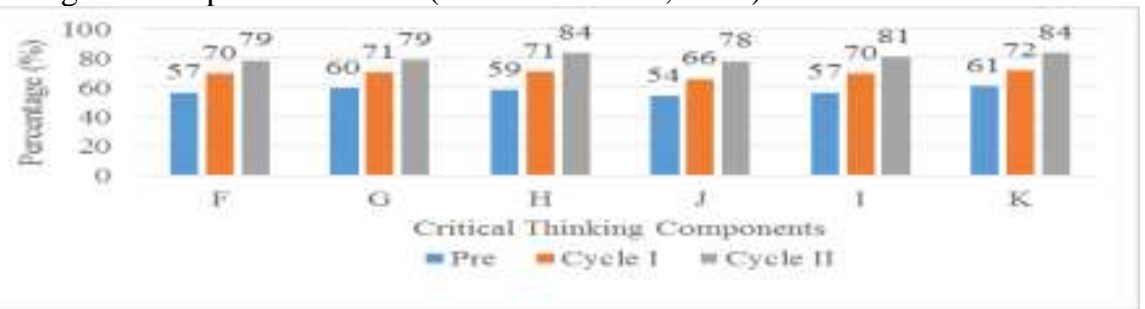

Figure 2

The percentage of students' critical thinking score improvement per cycle

Note:

F. The Accuracy and the Willing of being Accurate

G. Clear and the willing of attempting the clearness

H. Open-Minded

I. Avoiding an Impulsiveness

J. Taking Decision when there is a guarantee

K. The Sympathy of other sense and capability

Appropriate teaching strategies and learning environment strengthen learners' persistence, self-monitoring, open-minded, and flexible attitudes (King et al., n.d.). Tayler (2001) stated that an effective interaction between teacher and students can be guaranteed by ensuring the need for teachers to listen their students and to get them well. Therefore, the sensitive educators can make proper decision whether they have or have not to intervene their students (Venville, 2002). 
The upward trend of the data gained was also supported by the quality of the both questions and statements posed by students during the discussion sessions in the classroom. Most of students started their questions with the analysis undergirding. In one of discussion session, Dyah asked her question:

"Your team stated that recycle is the proper method to minimize non-degradable rubbish, yet in Indonesia, the recycle technology is still limited. It means that the technology available still far unbalance with the rubbish produced by the Indonesian consumptive people, what are your team arguments facing this facts?"

The above question shows the critical statement in which the student wanted to clarify whether the solution offered by the other team is relevant with the context. Susetyarini et al. (2015) stated that critical thinking skill is indicated by some aspects i.e. clarity, accuracy, precision, relevance, logic, breadth, depth, honesty, information, and implication. The analytical questions can stimulate learners to think critically. By having the skill to construct these kind of questions, the teacher candidates not only think themselves, but also encourage their students to do the same (Venville, 2002) and to generate multiple solutions (Resnick, 1987). Critical thinking skill is indicated by: question posing, decision making, and systemic thinking (Dillon \& Scott, 2002; Zohar \& Dori, 2003; Zoller, 2002), explore and explain problems, ideas, action, misunderstandings, agreements (Venville, 2002).

Ideally, the critical thinking skill improvement must be integrated with the knowledge level as well as its application in individual daily activities. As the common sense in analysing critical situations cultivated, naturally, thinking skills are also elevated. Thus, the students' ability to apply wise judgment or produce a reasoned critique (Brookhart, 2010) can be well enacted. OIDDE has been proven effectively develop the biology teacher candidates' ability in making ethical decision (Pantiwati et al., 2016). In line with Minarno (2001) who stated that communicating decisions through various opinions, whether it is in line or contradict, is an invaluable activity to promote the learners' horizon and critical thinking skills.

In line with the two thinking skills mentioned, self-regulated and critical thinking, the students' creative thinking skill was considered well developed.

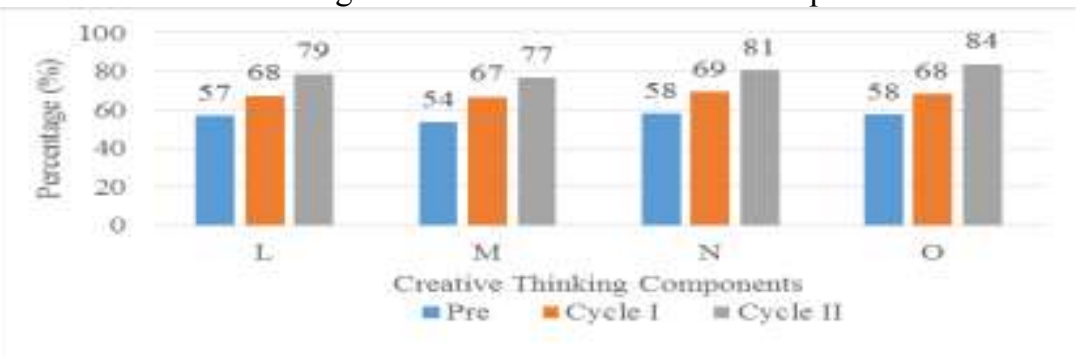

Figure 3

The percentage of students' creative thinking score improvement per cycle 
Note:

L. Taking efforts continuously in finishing the tasks even though the answer still cannot be forecasted

M. Self-encouragement of trying something which cannot confidently be done by themselves.

N. Productivity, Trusty, Using standard in evaluating his/her work results

O. Making new different point of view compare to the common.

The bar chart of Figure 3 shows the percentage of creative thinking skill improvement witnessed by learners who were taught by using OIDDE learning model. It can be seen clearly that each sub component experienced rising trend. The highest improvement of this skill was in the learners' ability in 'making new different point of view instead of using the common one' $(\mathrm{O})$, the change value was of $26 \%$, started from $58 \%$ in pre cycle to $84 \%$ in cycle II. While the lowest change value was in sub component $\mathrm{L}$ which represents the ability of 'conducting continuous endeavours in completing tasks albeit the results cannot be predicted'. Notwithstanding that this sub component was the lowest, as of $22 \%$, it was still considered as "very good" category as the last result value was $79 \%$.

Creative thinking is defined, as summarized by Agars et al. (2007), as the production of novel, useful ideas, and believed to associate with the right brain (Kim \& Michael, 1995). The novelty, in science domain, is often explained as problem solving (Newton, 2013). It is characterized by information processing in a direct and synthesis way (Torrance et al., 1977). Creative thinking skills are strongly related to the ability in generating new ideas. As the individuals' creative thinking develop, they will possess the abilities in managing their mind, initiating fresh ideas, broadening connections, having a lot of perspective on things, creating and imagining, and be result oriented (LTS, 2004).

This creative thinking skill can be figured out from student's statement written in their study journal in cycle II.

"The waste management discussion has reminded me about the issue occurred in my village. One day, in Madura, there was a group of people who said that they came to erect a waste recycle machine there. Having explained the benefits of the technology offered, we felt pleased in case the machine would be well run in our village, considering the way we just piling up the waste. However, after a while the existence of the machine, another problem arose. Trash pickers were mad and tried to destroy the machine due to the loss of their job. I started to think that the waste issue cannot be encountered by only considering one side benefit and ignoring the others. The use of technology in tackling the waste problem must be balanced with the efforts in cultivating society awareness of the importance of having the technology among them, besides preparing alternative solutions for the possible issues arise caused by the technology offered".

Student's written opinion above implied the complexity of thinking as considerable as the attempt in making relation of some aspects connected. The students learn their experiences from both community and school which will help them learn higher order thinking skills (King et al., n.d.). One of HOTS criteria for science listed in Florida 
Sunshine State Standards (Florida Department of Education, 1996) was 'understands the interconnectedness of the systems on earth and the quality of life'.

Successful higher order thinking depends upon a learner's ability to apply, reorganize, and embellish knowledge in the context of the thinking situation (King et al., n.d.). Teachers, somehow, are a part of society components who must give their contributions to the civilization advancement. Thus, they have to possess the attributes needed, including sensitivity and caring towards the environment, to support them in many aspects. Moreover, the individuals' awareness to gain more information and to equip themselves with high scientific capacity can be improved as their expertise and caring attitude are built which lead them to have thinking skills (Susetyarini et al., 2015).

Considering the findings, it can be said that the three thinking skills are supporting each other. The higher the self-regulated thinking score, the more critical and creative the learners will be. This in line with the findings of Husamah \& Pantiwati (2014) who revealed that all components of thinking skills were interrelated, influencing one another, and unified. Meanwhile, Kristiyani \& Lestyarini (2011) concluded that students' critical and creative character traits were showed in components of critical thinking and critical thinking skills which integrated the four abilities: building ideas, conducting reflective assessment, performing self-regulation, and recognizing the trait and behaviour.

Notwithstanding that the improvement of the student's HOTS were achieved in these research conditions, the implementation of OIDDE in different and more complex cases, as considerable as to measure the other student's thinking skills are needed to measure its effectiveness. Therefore, the further studies relating to OIDDE implementation are crucial to be conducted.

\section{CONCLUSION}

According to the current study, it can be concluded as follows: 1) OIDDE learning models has improved the students' higher order thinking skills (performed in: selfregulated thinking skill, critical thinking skill, and creative thinking skill), 2) the all thinking components are unity and supporting each other, the greater the self-regulated thinking skill, the better the ability in critical and creative thinking and vice versa, 3) the results showed that OIDDE has risen the each component of thinking skills from the 'low' category of $59 \%, 58 \%$, and $57 \%$ to 'very good' category of $82 \%, 81 \%$, and $80 \%$ for self-regulated thinking, critical thinking, and creative thinking respectively in which the significant value of the three thinking skill components were less than 0.05 ; i.e. 0.000 .

There are some limitations that may affect the results of this class action research. In the study measurement of HOTS was conducted using critical thinking assessment rubric by Marzano (1992). Students are required to fill the rubric in a relatively limited time, in 510 minutes at the end of learning. This scale was used to measure the HOTS of students because of the limited time and personal to measure the ability of students. However, students can fill the rubric with dishonest and in an unserious manner. Therefore the result can be different from the conditions that they really felt/think. In addition, rubrics 
developed by Marzano 35 years ago. Therefore, they can have the statements which do not reflect the current conditions. Moreover, the scale cannot be suitable for the students who are the participants of the study because of the cultural differences in Europe and Southeast Asia. As a result, the suggestion of this research is to develop a new HOTS rubric, which is more suitable to the condition of Southeast Asian society, especially Indonesia. HOTS measurements also need to be compared with self-reflection records and progressive reflection records written by students so as to obtain valid and balanced student HOTS information. Research on the implementation of the OIDDE learning model in other courses at different levels of semester also needs to be done to reinforce the conclusion that this learning model is applicable.

\section{REFERENCES}

Agars, M. D., Kaufman, J. C., \& Locke, T. R. (2007). Social influence and creativity in organizations: a multi-level lens for theory, research, and practice. Research in Multi Level Issues, 7(7), 3-61. http://doi.org/10.1016/S1475-9144(07)00001-X

Akbar, S. (2013). Instrumen perangkat pembelajaran. Bandung: PT Remaja Rosdakarya.

Anastasiades, P. S., \& Vitalaki, E. (2011). Promoting internet safety in Greek primary schools: the teacher's role. Educational Technology and Society, 14(2), 71-80.

Baker, E. L. (1989). Higher Order Assessment and Indicators of Learning. Los Angeles. Retrieved from http://cresst.org/wp-content/uploads/TR295.pdf

Ball, D. L., \& Forzani, F. M. (2009). The work of teaching and the challenge for teacher education. Journal of Teacher Education, 60(5), 497-511. http://doi.org/10.1177/0022487109348479

Bashir, S., Bajwa, M., \& Rana, S. (2014). Teacher as a role model and its impact on the life of female students. International Journal of Research -Granthaalayah, 1(1), 9-20.

Boekaerts, M., \& Corno, L. (2005). Self-regulation in the classroom: a perspective on assessment and intervention. Applied Psychology, An International Review, 54(4), 199231.

Brookhart, S. M. (2010). How to Assess Higher-Order Thinking Skills in Your Classroom. Alexandria. Retrieved from http://www.ascd.org/ASCD/pdf/books/brookhart2010b_copyright.pdf

Brown, M. E., \& Trevino, L. K. (2006). Ethical leadership: a review and future directions. The Leadership Quarterly, 17(6), 595-616. http://doi.org/10.1016/j.leaqua.2006.10.004

Chantarasombat, C. (2007). Development of Knowledge Management Model for Community Organization. Mahasarakham University.

Collins, R. (2014). Skills for the 21st century: teaching higher order thinking. Curriculum \& Leadership Journal, 12(14). Retrieved from 
http://www.curriculum.edu.au/leader/teaching_higher_order_thinking,37431.html?issueI $\mathrm{D}=12910$

Costa, A. L., \& Kallick, B. (2000). Describing 16 Habits of Mind Metacognition Perception. Alexandria: Association for Supervision and Curriculum Development. Retrieved from https://www.scribd.com/document/39455248/Describing-16-Habits-ofMind

Dillon, J., \& Scott, W. (2002). Perspectives on environmental education-related research in science education. International Journal of Science Education, 24(11), 1111-1117. http://doi.org/10.1080/09500690210137737

Dunlap, R. E., \& Jorgenson, A. K. (2012). Environmental problems. In The WileyBlackwell Encyclopedia of Globalization. Chichester, UK: John Wiley \& Sons, Ltd. http://doi.org/10.1002/9780470670590.wbeog174

Fadlan, A. (2010). Strategi peningkatan keterampilan calon guru dalam menerapkan pembelajaran aktif melalui MEI (Modelling, Engaging, and Integrating). Jurnal Kreatif: Jurnal Kependidikan Dasar, 1(1), 22-32. Retrieved from https://journal.unnes.ac.id/nju/index.php/kreatif/article/view/1667

Florida Department of Education. (1996). The Basic of School Improvement and Accountability in Florida. Tallahassee: Florida Department of Education.

Grossen, B. (1991). The fundamental skills of higher order thinking. Journal of Learning Disabilities. http://doi.org/10.1177/002221949102400603

Gullamhussesin, A. (2013). Teaching the Teachers, Effective Professional Development in an Era of High Stakes Accountability. Center for Public Education.

Handler, B. (2010). Teacher as curriculum leader: a consideration of the appropriateness of that role assignment to classroom-based practitioners. International Journal of Teacher Leadership, 3(3), 32-42.

Hoekstra, A., \& Korthagen, F. (2011). Teacher learning in a context of educational change: informal learning versus systematically supported learning. Journal of Teacher Education, 62(1), 76-92. http://doi.org/10.1177/0022487110382917

Hudha, A. M., Amin, M., Sumitro, S. B., \& Akbar, S. (2016). Study of instructional models and syntax as an effort for developing 'OIDDE' instructional model. Jurnal Pendidikan Biologi Indonesia, 2(2), 109-124. DOI: https://doi.org/10.22219/jpbi.v2i2.3448

Husamah, \& Pantiwati, Y. (2014). Cooperative learning STAD-PJBL: Motivation, thinking skills, and learning outcomes of biology department students. International Journal of Education Learning and Development, 2(1), 77-94. Retrieved from http://www.eajournals.org/wp-content/uploads/Cooperative-Learning-Stad-PjblMotivation-Thinking-Skills-And-Learning-Outcomes-of-Biology-DepartmentStudents2.pdf 
Husamah, H. (2015). Blended project based learning: Metacognitive awareness of biology education new students. Journal of Education and Learning (EduLearn), 9(4), 274-281. DOI: http://dx.doi.org/10.11591/edulearn.v9i4.2121

Joyce, B., \& Weil, M. (1978). Models of Teaching (Second). Englewood Cliffs, New Jersey: Prentice-Hall, Inc.

Kenimer, A., \& Morgan, J. (2003). Active learning exercises requiring higher-order thinking skills. In ASEE Annual Conference Proceedings.

Kim, J., \& Michael, W. B. (1995). The relationship of creativity measures to school achievement and to preferred learning and thinking style in a sample of Korea high school students. Educational and Psychological Measurement, 55(1), 60-74.

King, F., Goodson, L., \& Rohani, F. (n.d.). Higher Order Thinking Skills. Tallahassee. Retrieved from www.cala.fsu.edu

King, F., Goodson, L., \& Rohani, F. (1998). _Higher order thinking skills vs (opp). Research Developments.

Kristiani, A., \& Lestyarini, B. (2011). Survey on indicators of critical and creative thinking of prospective teachers in state university of Yogyakarta. Yogyakarta.

Larkin, S. (2002). Creating metacognitive experiences for 5- and 6-year-old children. In M. Shayer \& P. Adey (Eds.), Learning Intelligence: Cognitive Acceleration across the Curriculum from 5 to 15 Years (p. 65). Buckingham: Open University Press.

Lestari, I., Nurmilawati, M., \& Santoso, A. M. (2015). Penerapan Problem Based Learning (PBL) untuk meningkatkan kemampuan berpikir kritis dan sikap sosial peserta didik kelas VIII. In Seminar Nasional Pendidikan Biologi 2015 " Peran Biologi dan Pendidikan Biologi dalam Menyiapkan Generasi Unggul dan Berdayasaing Global " (pp. 465-471). Malang: UMM Press. Retrieved from research-report.umm.ac.id

LTS. (2004). Learning Thinking. Scotland: Learning and Teaching Scotland.

Lunenberg, M., Korthagen, F., \& Swennen, A. (2007). The teacher educator as a role model. Teaching and Teacher Education, 23, 586-601. http://doi.org/10.1016/j.tate.2006.11.001

Martin, D. S. (1989). Higher-order thinking. Journal of Teacher Education. http://doi.org/10.1177/002248718904000301

Marzano, R. J. (1992). A Different Kind of Classroom: Teaching with Dimensions of Learning. Alexandria: Association for Supervision and Curriculum Development. Retrieved from http://files.eric.ed.gov/fulltext/ED350086.pdf

Minarno, E. B. (2001). Pembelajaran bioetika secagai pengawal perkembangan biologi modern dan penyelamatan lingkungan hidup. el-Hayah, 3(1). http://doi.org/10.18860/elha.v3i1.2217

Minocha, S., Schroeder, A., \& Schneider, C. (2010). Role of the educator in social 
software initiatives in further and higher education: a conceptualisation and research agenda. British Journal of Educational Technology, 42(6), 889-903. http://doi.org/10.1111/j.1467-8535.2010.01131.x

Mukeredzi, T. G. (2013). Professional development through teacher roles: conceptions of professionally unqualified teachers in rural south africa and zimbabwe. Journal of Research in Rural Education, 28(11), 1-16.

National Research Council. (2009). A New Biology for the 21st Century. United States of America: The National Academies Press. http://doi.org/10.17226/12764

Nesbitt-Hawes, P. J. (2005). Higher Order Thinking Skills In Science Classroom Computer Simulation. Queensland University of Technology, Brisbane. Retrieved from https://eprints.qut.edu.au/16201/1/Philip_Nesbitt-Hawes_Thesis.pdf

Newton, D. P. (2013). Moods, emotions and creative thinking: a framework for teaching. Thinking Skills and Creativity, 8, 34-44. http://doi.org/10.1016/j.tsc.2012.05.006

Oak, M. (2009). Developing Critical Thinking Skills. Retrieved September 30, 2015, from http://www.buzzle.com/articles/developing-critical-thinking-skills.html

Okeke, C., \& Drake, M. (2014). Teacher as role model: the South African position on the character of the teacher. Mediterranean Journal of Social Science, 5(20), 17281737. http://doi.org/10.5901/mjss.2014.v5n20p1728

Pantiwati, Y., Husamah, \& Hudha, A. M. (2016). OIDDE Learning Model Through Integrated Field Study-Abroad to Develope Ethical Decision Skills of Biology Teacher Candidates. Malang.

Pukdeewut, S., Chantarasombat, C., \& Satapornwong, P. (2013). Creative thinking development program for learning activity management of secondary school teachers. International Education Studies, 6(12). http://doi.org/10.5539/ies.v6n12p82

Resnick, L. B. (1987). Education and Learning to Think. Washington, D.C.: National Academies Press.

Rustaman, N. Y. (2008). Scientific education and research in developing higher thinking skill for character building. In 8th National Seminar of Biology Education. Semarang: UNS.

Selvi, K. (2010). Teachers' competencies. Cultura International Journal of Philosophy of Culture and Axiology, 7(1), 167-175. http://doi.org/10.5840/cultura20107133

Setyaningrum, Y., \& Husamah, H. (2011). Optimalisasi penerapan pendidikan karakter di sekolah menengah berbasis keterampilan proses: Sebuah perspektif guru IPA-Biologi. Jurnal Penelitian dan Pemikiran Pendidikan, 1(1), 69-81.

Setyawan, D. (2017). Penerapan pembelajaran OIDDE pada matakuliah Zoologi Vertebrata untuk meningkatkan kemampuan berpikir kritis dan hasil belajar mahasiswa Pendidikan Biologi Universitas Muhammadiyah Malang. In Prosiding Seminar 
Nasional III Tahun 2017 "Biologi, Pembelajaran, dan Lingkungan Hidup Perspektif Interdisipliner" (pp. 196-203). Malang. Retrieved from research-report.umm.ac.id

Shaik, Z. A., \& Khoja, S. A. (2011). The role of ICT in shaping the future of Pakistan higher education system. The Turkish Online Journal of Educational Technology, 10(1), 2011.

Shaikh, Z., \& Khoja, S. (2012). Role of teacher in personal learning environments. Digital Education Review, 21(June), 23-32.

Susetyarini, R. E., Wahyuni, S., \& Latifa, R. (2015). Kemampuan berpikir kritis mahasiswa pada matakuliah embriologi dan reproduksi hewan melalui lesson study. In Prosiding Seminar Nasional Pendidikan Biologi. Retrieved from http://biology.umm.ac.id/files/file/774-781 Rr_Eko Susetyarini.pdf

Syamsuri, I., \& Ibrohim. (2011). Lesson Study (Studi Pembelajaran). Malang: UM Press.

Tayler, C. (2001). Australian early childhood milieu: Teacher challenges in promoting children's language and thinking. European Early Childhood Education Research Journal, 9(1), 41-56. http://doi.org/10.1080/13502930185208671

Torrance, E. P., Reynolds, R. C., Riegel, T., \& Ball, O. (1977). Your style of learning and thinking, forms $\mathrm{a}$ and $\mathrm{b}$ preliminary norms, abbreviated technical notes, scoring keys, and selected references. The Gifted Child Quarterly, 21(4), 563-573. http://doi.org/10.1177/001698627702100417

Venville, J. G. (2002). Enhancing the quality of thinking in year 1 classes. In M. Shayer $\&$ P. Adey (Eds.), Learning Intelligence: Cognitive Acceleration across the Curriculum from 5 to 15 Years (p. 35). Buckingham: Open University Press.

Yee, M. H., Md Yunos, J., Othman, W., Hassan, R., Tee, T. K., \& Mohamad, M. M. (2012). The Needs Analysis of Learning Higher Order Thinking Skills for Generating Ideas. Procedia - Social and Behavioral Sciences. http://doi.org/10.1016/j.sbspro.2012.09.265

Zohar, A., \& Dori, Y. J. (2003). Higher order thinking skills and low-achieving students: are they mutually exclusive? The Journal of the Learning Sciences, 2(2), 145181.

Zoller, U. (2002). Algorithmic, LOCS and HOCS (chemistry) exam questions: performance and attitudes of college students. International Journal of Science Education, 24(2), 185-203. http://doi.org/10.1080/09500690110049060 